\title{
Chromosomal Diversity in Two Allopatric Populations of Farlowella hahni Meinken 1937 (Teleostei: Siluriformes): Cytogenetics and Cytochrome $b$ Analyses
}

\author{
Carlos Alexandre Fernandes, ${ }^{1,2}$ Leonardo Marcel Paiz, ${ }^{2,3}$ Diovani Piscor, ${ }^{4}$ Mariane Gavazzoni, ${ }^{2,3}$ \\ Luciana Andreia Borin de Carvalho, ${ }^{1}$ Ana Luiza de Brito Portela-Castro, and Vladimir Pavan Margarido ${ }^{2,3}$
}

\begin{abstract}
Farlowella is the second richest genus in Loricariinae, broadly distributed in freshwater streams and rivers of South America. In this article, we aimed to expand on the cytogenetic and molecular data available for two allopatric populations of Farlowella hahni. Both populations had diploid chromosome number 58, but with karyotype differences, indicative of chromosomal rearrangements. C-banding showed large heterochromatic blocks at telomeric regions in acrocentric chromosomes in both populations. Fluorescence in situ hybridization (FISH) revealed a single $18 \mathrm{~S}$ rDNA site in both populations and a single $5 \mathrm{~S}$ rDNA site for individuals from lower Paraná River basin (native region) and multiple 5S rDNA sites for individuals from upper Paraná River basin (non-native region). Mitochondrial sequence analyses did not separate the two $F$. hahni populations. The cytogenetic and molecular data obtained are relevant in a preliminary study and suggested the existence of cryptic diversity and the hypothesis that at least two Farlowella lineages may coexist in the Paraná basin.
\end{abstract}

Keywords: mitochondrial sequence, ribosomal DNA, C-banding, chromosomal rearrangements, fish cytogenetics

\section{Introduction}

A MONG THE LORICARIINAE, Farlowella is the second richest genus in the subfamily with 30 valid species, ${ }^{1}$ broadly distributed in freshwater streams and rivers of the Amazon, Orinoco, Maracaibo, Paraná, and coastal drainages of the Guiana shield, ${ }^{2}$ being recently recorded for the MagdalenaCauca system. ${ }^{3}$ These catfish have an extremely thin and elongated body, a bony snout, and prominent tail filaments reaching a length of only $265 \mathrm{~mm}$. The wood-like appearance and elongated shape of these animals has earned them the common name of twig catfish, being utilized as ornamental fish. ${ }^{2,4}$ Farlowella hahni is a non-native species from the upper Paraná River (native from lower Paraná River basin), cited previously as $F$. amazonum for this part Paraná River, and its occurrence can be associated with the filling of the Itaipu Reservoir and the consequent inundation of the Sete Quedas Falls. ${ }^{5}$

Available cytogenetic data for Loricariinae show that the diploid number ranges from $2 n=36$ in Rineloricaria latirostris (Boulenger, 1900) ${ }^{6}$ to $2 n=74$ in Sturisoma cf. nigrirostrum
Fowler, 1940. ${ }^{7}$ Cytogenetic studies in Farlowella are rare and restricted to $F$. hahni (cited previously as $F$. amazonum), Farlowella cf. amazonum and F. schreitmuelleri, which have showed a diploid number of 58 chromosomes, but with minor karyotype differences between three species analyzed. ${ }^{8-10}$

In Loricariinae, physical mapping of $18 \mathrm{~S}$ rDNA were detected in three chromosomes for Rineloricaria lanceolata, ${ }^{11}$ in two chromosomes for Harttia loricariformis ${ }^{12}$ and individual females of Harttia punctata, ${ }^{13}$ in one chromosome of individual males $H$. punctata. $^{13}$ Physical mapping of $5 \mathrm{~S}$ rDNA in this subfamily were detected in $H$. punctata, located in two chromosomes for males or females. ${ }^{13}$ In Farlowella, cytogenetic studies on the distribution of ribosomal RNA (rRNA) genes are scarce, with single 18S rDNA sites in $F$. schreitmuelleri and Farlowella cf. amazonum and single 5S rDNA sites in Farlowella cf. amazonum and multiple 5S rDNA sites in F. schreitmuelleri. ${ }^{10}$

In this article, we aimed to expand on the cytogenetic and molecular data available for $F$. hahni, contributing to the first record of mapping of ribosomal DNA (5S and $18 \mathrm{~S}$ rDNA)

\footnotetext{
${ }^{1}$ Departamento de Biotecnologia, Genética e Biologia Celular, Universidade Estadual de Maringá, Maringá, Brazil.

${ }^{2}$ Programa de Pós-Graduação em Biologia Comparada, Universidade Estadual de Maringá, Maringá, Brazil.

${ }^{3}$ Centro de Ciências Biológicas e da Saúde, Universidade Estadual do Oeste do Paraná, Cascavel, Brazil.

${ }^{4}$ Universidade Estadual de Mato Grosso do Sul, Unidade Universitária de Mundo Novo, Dourados, Brazil.
} 
and cytochrome $b(C y t b)$ analyses in this species, including in the analyses, individuals of region native (lower Paraná basin) and individuals from non-native region (upper Paraná basin) of this species.

\section{Materials and Methods}

Six individuals of $F$. hahni were collected from populations of Paraná River basin (Fig. 1): two males and three females of
F. hahni from the Dourado stream, Upper Paraná River basin (Mundo Novo- MS; 2351'04,9"S and 54 ${ }^{\circ} 25^{\prime} 13,9^{\prime \prime} \mathrm{W}$ ) and one individual of $F$. hahni from the Iguassu River, Middle Paraná River basin (preservation area of the Iguassu National ParkPR; $25^{\circ} 38^{\prime} 18.72^{\prime \prime} \mathrm{S} ; 54^{\circ} 28^{\prime} 4.74^{\prime \prime} \mathrm{W}$ ).

Animals were captured with the permission of the Instituto Chico Mendes de Conservação da Biodiversidade (ICMBio; number 45442 Voucher specimens were deposited in the fish collection of the Núcleo de Pesquisas em

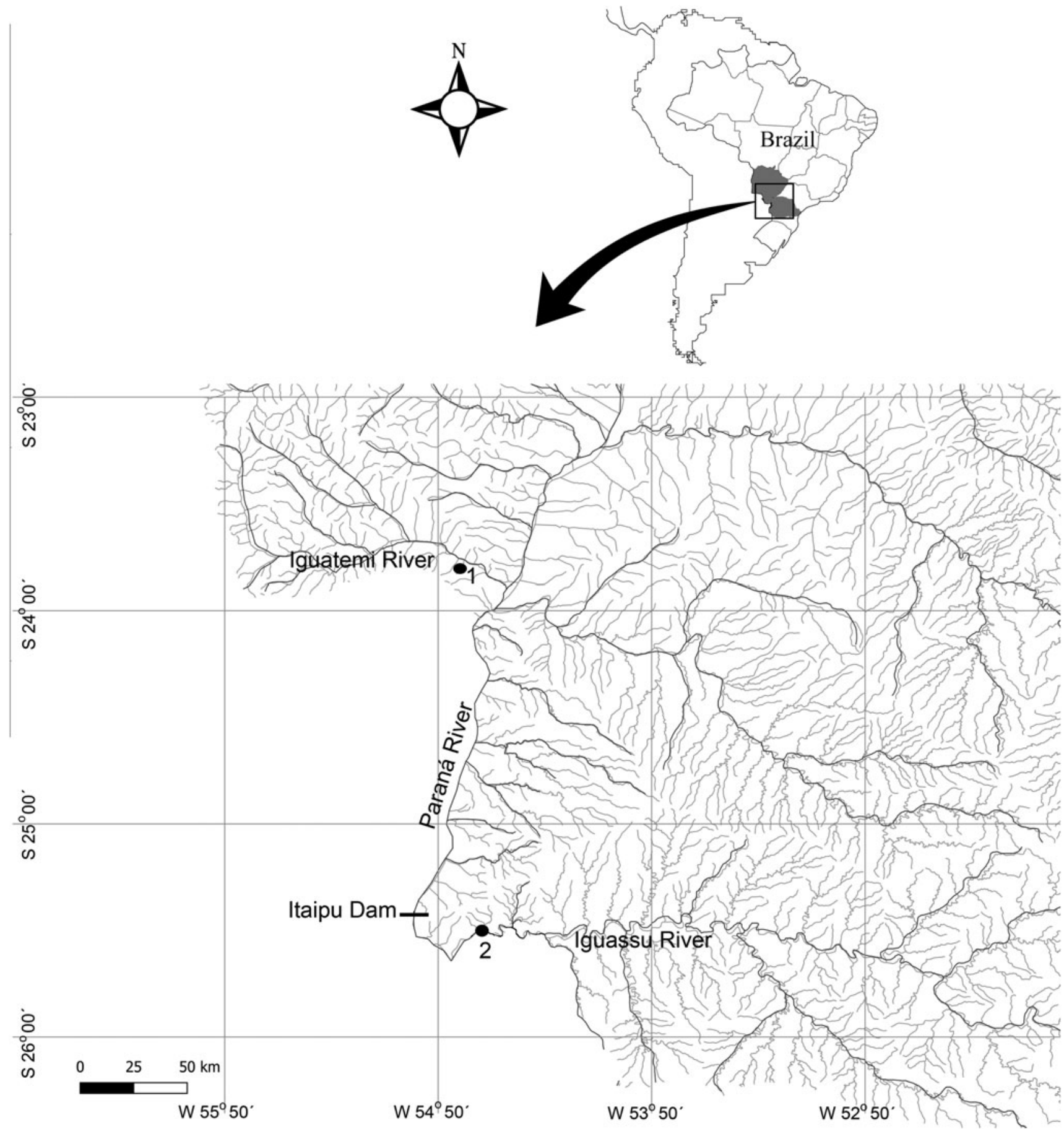

FIG. 1. Location of (1) Dourado stream (upper Paraná River basin) and (2) Iguassu River (middle Paraná River basin) where Farlowella hahni individuals were captured. Dark circle indicates the sampling spots. 
Limnologia, Ictiologia e Aquicultura (NUPELIA), Universidade Estadual de Maringá, PR Brazil, as F. hahni from Dourado stream (NUP 22695), and $F$. hahni from Iguassu River (NUP 22696).

This study was carried out in strict accordance with the recommendations of the Guide for the Care and Use of Laboratory Animals, approved by the Committee on Ethics of Animal Experiments of the Universidade Estadual do Mato Grosso do Sul (License Number: Protocol 024/2018CEUA/UEMS). The experiments followed the ethical conduct, and before euthanasia, the fish were anesthetized by an overdose of clove oil. ${ }^{14}$

\section{Cytogenetics analyses}

Metaphase chromosomes were obtained from anterior kidney cells using the air-drying technique. ${ }^{15}$ The $\mathrm{C}$-positive heterochromatin (C-bands) visualized by the procedure of Sumner, ${ }^{16}$ with some minor adaptations. ${ }^{17}$

At least 30 metaphases were analyzed for each individual and those with better chromosome morphology were used for the karyotype analysis. The chromosomes were classified as metacentric $(\mathrm{m})$, submetacentric $(\mathrm{sm})$, subtelocentric $(\mathrm{st})$, and acrocentric (a) according to Levan et al. ${ }^{18}$ The fundamental number $(\mathrm{FN})$ was calculated according to the chromosomal arm numbers (the chromosomes $m$, sm, and $s t$ were considered to contain two arms $-p$ and $q$ arms — and the $a$ with one arm-only $q$ arm).

The location of the $5 \mathrm{~S}$ and $18 \mathrm{~S}$ rDNA sites in the chromosomes was performed by fluorescence in situ hybridization (FISH) ${ }^{19}$ with modifications, ${ }^{20}$ using probes from the genome of Megaleporinus elongatus (Valenciennes, 1850) ${ }^{21}$ and Prochilodus argenteus Spix and Agassiz, $1829,{ }^{22}$ respectively. The probes were labeled through nick translation, with digoxigenin-11-dUTP (5S rDNA) and biotin-16-dUTP (18S rDNA) (Roche). Detection and amplification of the hybridization signal were carried out using avidin-FITC and anti-avidin biotin (Sigma) for probes labeled with biotin, and anti-digoxigenin rhodamine (Roche) for probes labeled with digoxigenin. Chromosomes were counterstained with DAPI $\left(50 \mu \mathrm{g} \mathrm{mL}^{-1}\right)$ and analyzed in epifluorescence microscope (Olympus BX61). The images were captured using the software DP controller (Media Cybernetics) and the image composition with Adobe Photoshop CS6.

\section{Molecular analyses}

For molecular analyses of mitochondrial data we used six specimens of $F$. hahni. Farlowella platoryncha (GenBank: DQ133779.1) and Rineloricaria fallax (GenBank: DQ133780.1) were used as outgroup. Extraction of total DNA from hepatic tissue preserved in $100 \%$ ethanol was performed with the GenElute ${ }^{\mathrm{TM}}$ Mammalian Genomic DNA Miniprep Kit (Sigma-Aldrich) following manufacturer's recommendations. The genomic DNA was quantified on the nanospectrophotometer NanoK (Kasvi) and then diluted to a concentration of $10 \mathrm{ng} / \mu \mathrm{L}$. For amplification of mitochondrial genes $C y t \quad b$ we used the primers $\operatorname{GluDGF}^{23}$ and H16460R. ${ }^{24}$ The final polymerase chain reaction (PCR) products were purified using the Wizard Kit SV Gel and PCR Clean-up System (Promega), according to the manufacturer's guidelines. Samples were sequenced by Sanger Method using BigDye $^{\circledR}$ Terminator v3.1 Cycle Sequencing Kit and per- formed on an ABI 3730 DNA Analyzer at the Centro de Pesquisa do Genoma Humano, Universidade de São Paulo, Brazil.

Sequences were then edited with BioEdit ${ }^{25}$ and aligned with MUSCLE algorithm ${ }^{26}$ implemented on MEGA X. ${ }^{27}$ Saturation signal was checked by DAMBE v7.0.28, ${ }^{28}$ and the best-fitting model was chosen using the Akaike Information Criterion using jModelTest $2 .^{29}$ The evolutionary history was inferred by using the neighbor-joining (NJ) based on the Kimura 2-parameter method and the maximum likelihood (ML) method based on the Hasegawa-Kishino-Yano model with Gamma distribution (five categories $[+\mathrm{G}$, parameter $=0.2988]$ ), with 1000 bootstrap replicates, were conducted in MEGA X. ${ }^{27}$ Species delimitation was performed using the ABGD model (Automatic Barcode Gap Discovery $)^{30}$ at http://wwwabi.snv.jussieu.fr/public/abgd/ abgdweb.html, using as input a fasta file; the Kimura distance model (K80) and the simple distance were analyzed in the result.

\section{Results}

\section{Cytogenetics analyses}

F. hahni-lguassu River (lower Paraná River basin). Diploid number was 58 chromosomes $(12 m+20 s m+22 s t+4 a$, $\mathrm{FN}=112$ ) (Fig. 2a). C-banding showed large heterochromatic blocks at telomeric region in the long arm of pair 29 and interstitial position proximal to the telomeric region in the long arm of pair 28 , and at pericentromeric regions in the long arm of pairs 22, 28, and 29, besides centromeric markings in some chromosomes (Fig. 2c). FISH revealed a single $5 \mathrm{~S}$ rDNA site in pericentromeric position in the st pair 22 and a single $18 \mathrm{~S}$ rDNA site in terminal position on the short arm of the $a$ pair 28 (Fig. 2e).

F. hahni-Dourado stream (upper Paraná River basin). Diploid number was 58 chromosomes $(12 m+30 s m+10 s t+6 a$, $\mathrm{FN}=110$ ) for males and females (Fig. 2b). C-banding showed large heterochromatic blocks at telomeric regions in the long arm of pairs 27 and 28 and at pericentromeric regions in the long arm of pairs 8, 14, 24, 27, and 28, besides centromeric markings in some chromosomes (Fig. 2d). FISH revealed multiple $5 \mathrm{~S}$ rDNA sites in pericentromeric position in the $s t$ pairs 24 and 27, and in the subterminal/terminal position of $a$ pairs 27 and 28, respectively, and a single 18S rDNA site in terminal position on the $q$ arm of the $a$ pair 27, with a clear size heteromorphism (Fig. 2f).

\section{Molecular analyses}

Sequences are available in the GenBank with the following accession numbers: MW269961-MW269966. The $C y t b$ matrix contains six terminals and $986 \mathrm{bp}$ with one variable site, further two terminals as outgroup (Supplementary File S1). The overall mean and pairwise genetic distances between the two populations of $F$. hahni were statistically insignificant. Both trees resulting from the phylogenetic analysis (NJ and ML) evidenced that specimens analyzed in this study formed a monophyletic group with high bootstrap values (Fig. 3). The ABGD model (Supplementary File S2) for species delimitation showed the same arrangement as that of NJ and ML. 
a

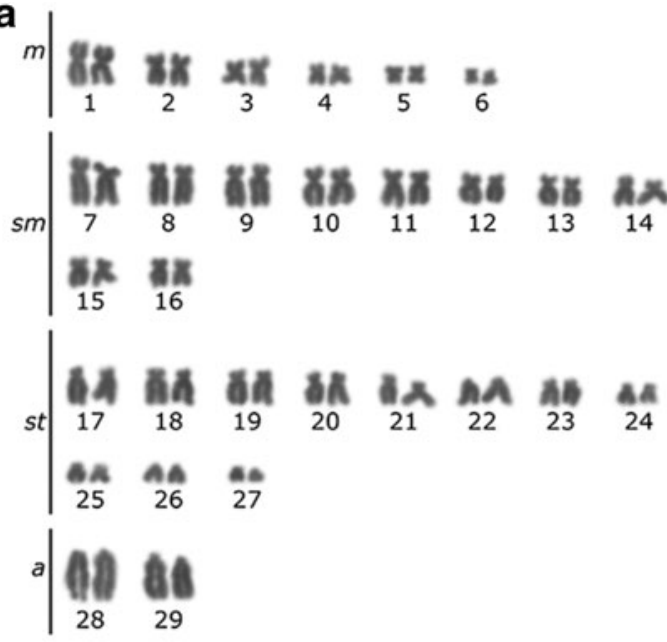

C
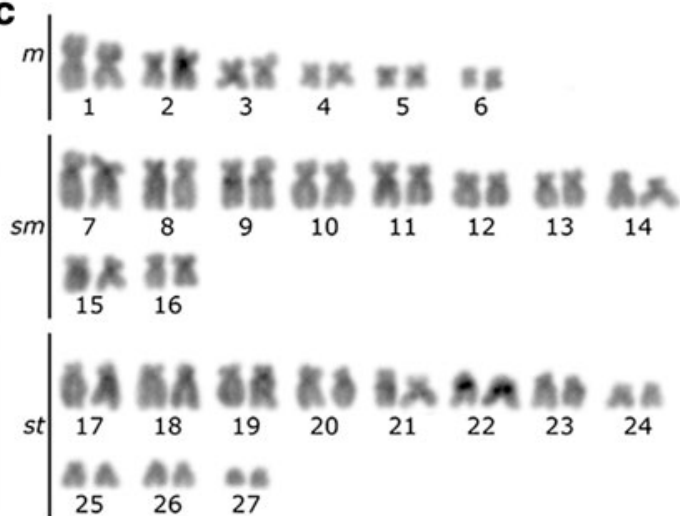

b

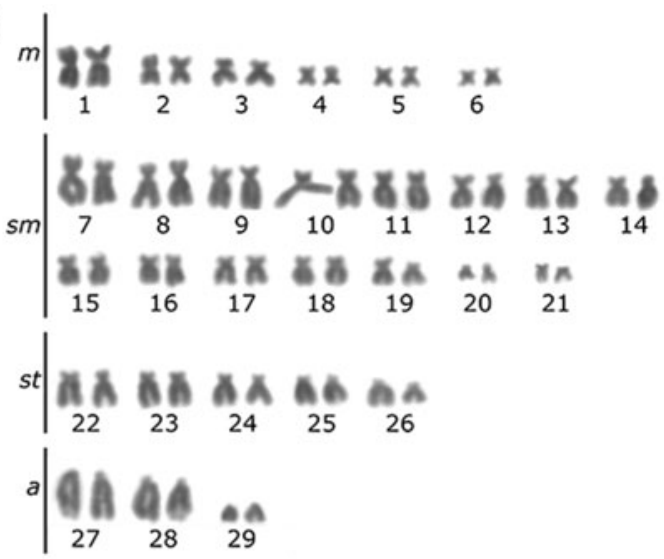

d
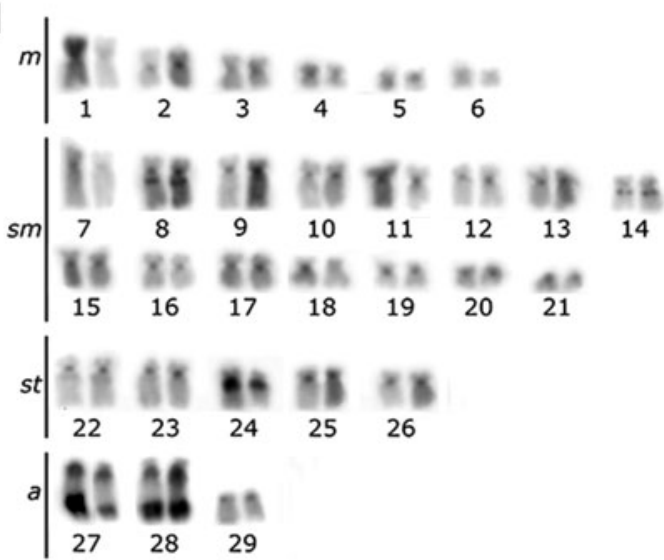
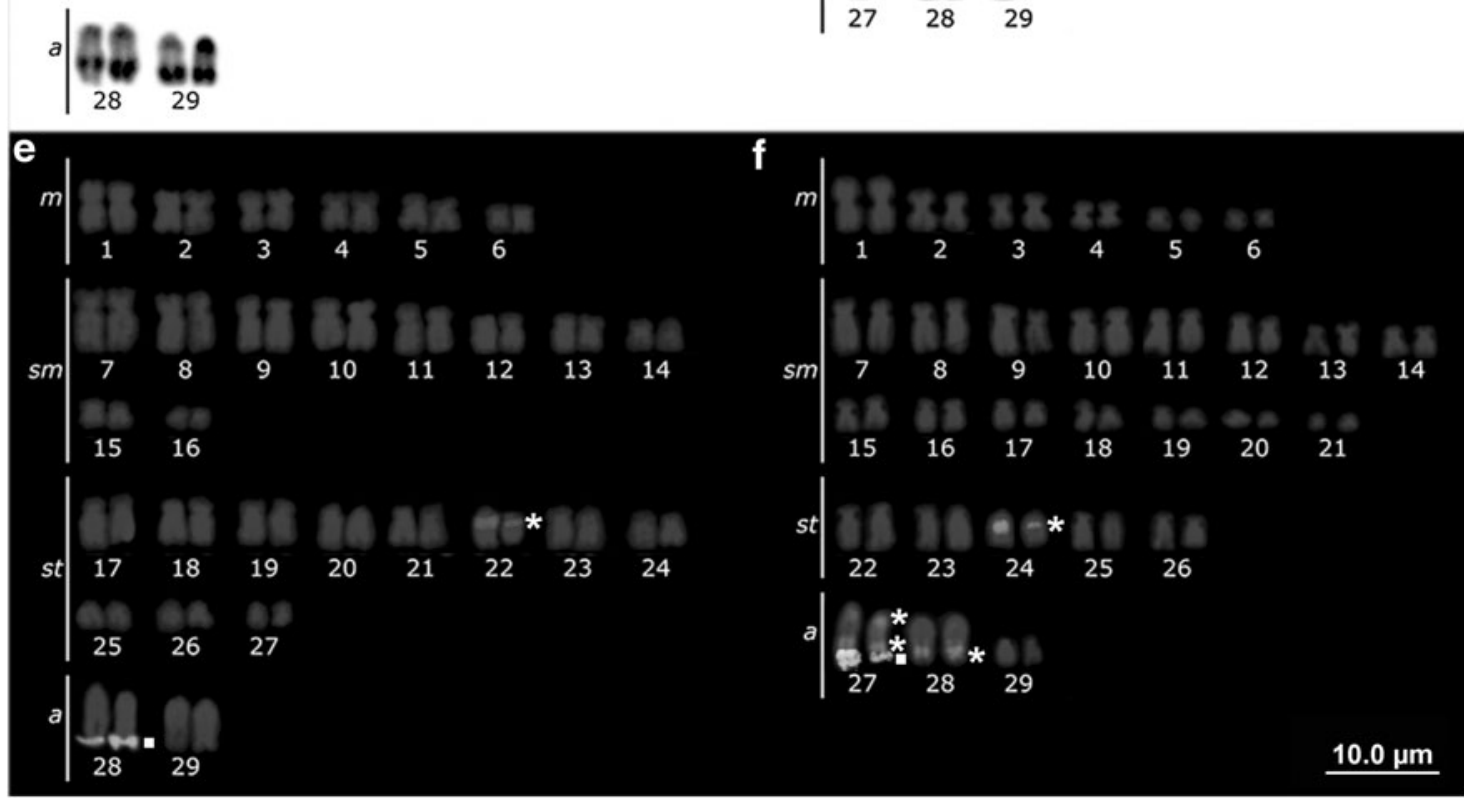

FIG. 2. Karyotypes (a, c, e) Farlowella hahni from Iguassu River, (b, d, f) F. hahni from Dourado stream. Karyotypes (a, b) stained with Giemsa, (c, d) C-banded and (e, f) after double FISH with 5S rDNA probes (asterisk) and 18S rDNA (square). FISH, fluorescence in situ hybridization.

\section{Discussion}

A diploid number of 58 chromosomes has been identified invariably in Farlowella species, including Farlowella cf. amazonum, $F$. schreitmuelleri ${ }^{10}$ and different $F$. hahni po- pulations as shown in Fernandes et al. ${ }^{8,9}$ and the present study. A number of chromosomal rearrangements, such as pericentric inversions and/or deletions are found in the genomes of $F$. hahni analyzed in this study, given that, although they have the same $2 n$, the FN value and the karyotypes are 


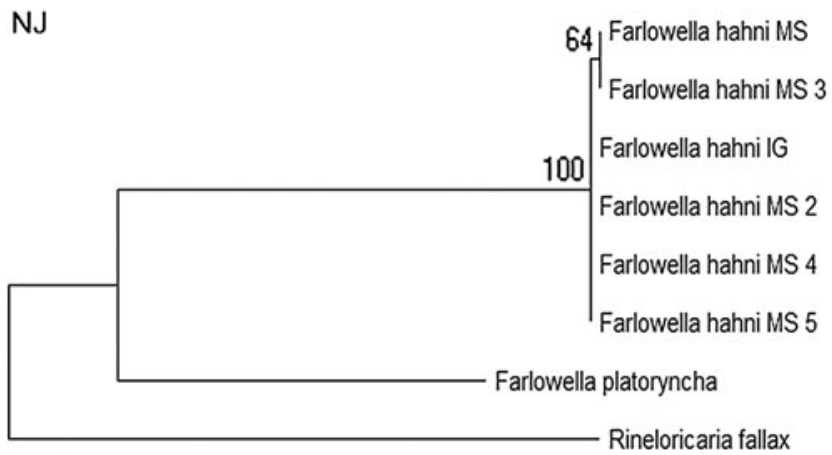

0.020

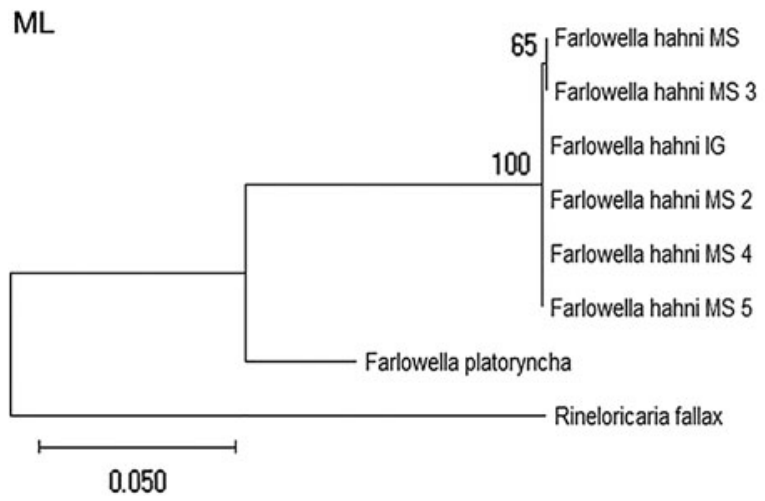

FIG. 3. Relationship cladograms performed with cytochrome $b$ sequences generated by NJ and ML analyses. Bootstrap values are represented in the branches. Farlowella platorynchus and Rineloricaria fallax were used as outgroup. ML, maximum likelihood; NJ, neighbor-joining.

different, which the separation geographic and reduced vagility of species, which may lead to the formation of small isolated populations, may have facilitated the establishment of this karyotype variation due to the restriction of gene flow between them.

In the Farlowella species analyzed up to now, the nucleolar organizer region (NOR) phenotype is simple, as confirmed by the $18 \mathrm{~S}$ rDNA probe as shown in Fernandes et al. ${ }^{8,9}$ and Marajó et al. ${ }^{10}$ and the present study. In the karyotype of $F$. hahni under study, whereas in those of $F$. schreitmuelleri ${ }^{10}$ and $F$. hahni previous studies, ${ }^{8,9}$ the NORs are found on the long arms of the first acrocentric pair, which appears to be a conserved pattern in this genus, except in Farlowella cf. amazonum ${ }^{10}$ the NOR site is located in the pericentromeric region of the long arms of the first metacentric pair.

In this study, size heteromorphism involving the NORs was detected by $18 \mathrm{~S}$ rDNA-FISH only in the individuals of $F$. hahni from upper Paraná River basin. These different-sized regions between homologs may be the result of differences in the copy numbers of ribosomal genes. ${ }^{31,32}$ This characteristic can be explained mainly by unequal recombination or random duplication in ribosomal cluster. ${ }^{33}$

Physical mapping of 5S rDNA in genome of $F$. hahni showed differences between populations analyzed. The $5 \mathrm{~S}$ rDNA is located in a single chromosome pair for individual from Iguassu River, whereas for individuals from Dourado stream is located in three chromosome pairs. The large var- iation in the number of 5S rDNA cistrons may suggest the occurrence of pseudogeneization events or the insertion of mobile genetic elements (TEs) in the 5S rDNA intergenic spacers in $F$. hahni from upper Paraná basin, promoting the detection of "extra" sites of this gene through FISH. In both populations studied here, the 5S rDNA sites were associated with constitutive heterochromatin. The presence of sequences 5S rDNA in heterochromatic regions, and their association with TEs, are considered hotspots of genomic alterations, given that repetitive sequences are more susceptible to rearrangement, due to their intrinsic structural organization. ${ }^{34,35}$ The TEs inside 5S rDNA nontranscribed sequences (NTS) are well described in fish genomes. ${ }^{36-39}$

The situation where two or more 5S rRNA gene clusters are localized on the same chromosome is quite rare; however, it was reported for fish species, including Upsilodus sp., ${ }^{40}$ Hippoglossus hippoglossus (Linnaeus 1758), ${ }^{41}$ Trachydoras paraguayensis (Eigenmann and Ward 1907), ${ }^{42}$ Apteronotus albifrons (Linnaeus 1766), ${ }^{43}$ and Sternopygus macrurus (Bloch and Schneider 1801). ${ }^{44}$ Double 5S rDNA sites (both in $q$ arms) in the same chromosome observed in the karyotype of $F$. hahni from upper Paraná River basin, indicated that paracentric inversion might have caused the breakage of the $5 \mathrm{~S}$ rDNA cluster, then transferring part of the site to the same arm of the same chromosome. This type of signal was found in the individuals $F$. hahni from upper Paraná River basin may represent species-specific chromosome marker.

This study showed an accentuated accumulation of heterochromatin, with large conspicuous bands, found in acrocentric chromosome pairs in both $F$. hahni populations. This pattern was also observed in F. schreitmuelleri, ${ }^{10}$ whereas Farlowella cf. amazonum ${ }^{10}$ have less heterochromatin in comparison with aforementioned species. Thus, the distribution of heterochromatin can be useful as a cytotaxonomic marker among Farlowella, separating at least two groups, those with large heterochromatic blocks in acrocentrics $(F$. hahni and $F$. schreitmuelleri) and those with little heterochromatin (Farlowella cf. amazonum) spread throughout the genome.

Molecular data indicate the existence of one clade de $F$. hahni from Paraná River basin with low genetic differentiation. Although the molecular characters (e.g., $C y t b$ and cytochrome oxidase subunit I-COI-genes) are considered efficient for the identification of fish species, with effective results in several studies, ${ }^{45}$ this tool is less conclusive when compared with chromosomal data. Similar results were found in other studies in Astyanax. ${ }^{46-48}$ and in other complex groups, such as Rineloricaria ${ }^{49}$ and Prochilodus,${ }^{50}$ indicating that this gene may be less efficient for taxonomically complex clades with recent speciation.

According Júlio Júnior et al. ${ }^{51}$ fish species have invaded in the upper part of the Paraná River basin after the Itaipu Reservoir inundated Sete Quedas Falls, a natural and effective barrier that was the limit of two hydrographic ecoregions (upper Paraná River basin and lower Paraná River basin). The role of Sete Quedas Falls as a limit of these ichthyofaunistic regions was recognized by several authors. ${ }^{52-54}$ The Itaipu Dam, located $150 \mathrm{~km}$ downstream from Sete Quedas, impounded the River Paraná in 1982 and completely flooded the falls. Therefore, several species endemic to the lower Paraná River basin successfully colonized and spread over the upper Paraná River. This is case of $F$. hahni, a native species from lower Paraná River basin. ${ }^{4,55}$ Thus, the fact of $F$. hahni to colonize the upper 
Paraná River recently may have contributed to this chromosomal differentiation between the populations analyzed in this study. Therefore, we can conclude that chromosomal evolution in $F$. hahni is not followed by the $C y t b$ gene variation, making it increasingly important to use integrative tools that include chromosomal markers in phylogenetic studies.

Cytogenetic data, such as karyotype formula and 5S rDNA sites were efficient to separate $F$. hahni from the upper Paraná River of $F$. hahni from the lower Paraná River. Overall, the cytogenetic and molecular data obtained are relevant in a preliminary study and suggested the existence of cryptic diversity and the hypothesis that at least two Farlowella lineages may coexist in the Paraná basin.

\section{Acknowledgments}

We thank Dr. Weferson Júnio da Graça for the taxonomic identification of the specimens. Besides, we are grateful to the Ministério do Meio Ambiente/Instituto Chico Mendes de Conservação da Biodiversidade (MMA/ICMBio-License number 45442) for authorizing the collection of the biological material.

\section{Disclosure Statement}

No competing financial interests exist.

\section{Funding Information}

This study was financed by CAPES (Coordenadoria de Aperfeiçoamento de Ensino Superior), Fundação Araucária (Fundação Araucária de Apoio e Desenvolvimento Científico e Tecnológico do Estado do Paraná) and CNPq (Conselho Nacional de Desenvolvimento Científico e Tecnológico).

\section{Supplementary Material}

Supplementary File S1

Supplementary File S2

\section{References}

1. Fricke R, Eschmeyer WN, Van der Laan R. Eschmeyer's catalog of fishes: genera, species, references. Calif Acad Sci 2020. Available at: http://researcharchive.calacademy .org/research/ichthyology/catalog/fishcatmain.asp Accessed October 4, 2020.

2. Covain R, Fisch-Muller S. The genera of the Neotropical armored catfish subfamily Loricariinae (Siluriformes: Loricariidae): a practical key and synopsis. Zootaxa 2007;1462:1-40.

3. Ballen GA, Mojica JI. A new trans-Andean Stick Catfish of the genus Farlowella Eigenmann and Eigenmann, 1889 (Siluriformes: Loricariidae) with the first record of the genus for the río Magdalena Basin in Colombia. Zootaxa 2014;3765:134-142.

4. Ferraris CJ Jr. Subfamily Loricariinae (armored catfishes). In: Check List of the Freshwater Fishes of South and Central America. Reis R, Kullander S, Ferraris C Jr. (eds), pp. 330-350, Edipucrs, Porto Alegre, Brazil, 2003.

5. Ota RR, Deprá G de C, Graça WJ da, Pavanelli CS. Peixes da planície de inundação do alto rio Paraná e áreas adjacentes: revised, annotated and updated. Neotrop Ichthyol 2018;16:1-111.

6. Giuliano-Caetano L: Polimorfismo cromossômico Robertsoniano em populações de Rineloricaria latirostris (Pisces, Loricariinae). Universidade Federal de São Carlos, São Paulo, 1998.
7. Artoni RF, Bertollo LAC. Trends in the karyotype evolution of Loricariidae fish (Siluriformes). Hereditas 2001;134:201-210.

8. Fernandes CA, Damásio JF, Martins-IC. Cytogenetic studies in species of family Loricariidae (Osteichthyes, Siluriformes) from Iguatemi river basin, Brazil. First cytogenetic report in Farlowella amazonum (Günther, 1864). Caryologia 2012;65:276-280.

9. Fernandes CA, Alves DS, Guterres Zda R, Martins-Santos IC. Cytogenetic analysis of two locariid species (Teleostei, Siluriformes) from Iguatemi River (Parana River drainage) in Brazil. Comp Cytogenet 2015;9:67-78.

10. Marajó L, Viana PF, Ferreira M, Py-daniel LHR, Feldberg E. Cytogenetics of two Farlowella species (Loricariidae: Loricariinae): implications on the taxonomic status of the species. Neotrop Ichthyol 2018;16:e180029.

11. Porto FE, Vieira MM, Barbosa LM, Borin-Carvalho LA, Vicari MR, Portela-Castro ALB, et al. Chromosomal polymorphism in Rineloricaria lanceolata Günther, 1868 (Loricariidae: Loricariinae) of the Paraguay basin (Mato Grosso do Sul, Brazil): evidence of fusions and their consequences in the population. Zebrafish 2014;11:318-324.

12. Kavalco KF, Pazza R, Bertollo LAC, Moreira-Filho O. Karyotypic diversity and evolution of Loricariidae (Pisces, Siluriformes). Heredity (Edinb) 2005;94:180-186.

13. Blanco DR, Vicari MR, Lui RL, Artoni RF, de Almeida MC, Traldi JB, et al. Origin of the X1X1X2X2/X1X2Y sex chromosome system of Harttia punctata (Siluriformes, Loricariidae) inferred from chromosome painting and FISH with ribosomal DNA markers. Genetica 2014;142:119-126.

14. Griffiths S. The use of clove oil as an anaesthetic and method for sampling intertidal rockpool fishes. J Fish Biol 2000;57:1453-1464.

15. Bertollo LAC, Takahashi CS, Moreira-filho O. Cytotaxonomic considerations on Hoplias lacerdae (Pisces, Erythrinidade). Braz J Genet 1978;1:103-120.

16. Sumner AT. A simple technique for demonstrating centromeric heterochromatin. Exp Cell Res 1972;75:304-306.

17. Lui RL, Blanco DR, Moreira-Filho O, Margarido VP. Propidium iodide for making heterochromatin more evident in the C-banding technique. Biotech Histochem 2012;87:433-438.

18. Levan A, Fredga K, Sandberg AA. Nomenclature for centromeric position on chromosomes. Hereditas 1964;52:201-220.

19. Pinkel D, Straume T, Gray JW. Citogenetic analysis using quantitative, high-sensitivity, fluorescence hybridization. Proc Natl Acad Sci U S A 1986;83:2934-2938.

20. Margarido VP, Moreira-filho O. Karyotypic differentiation through chromosome fusion and number reduction in Imparfinis hollandi (Ostariophysi, Heptapteridae). Genet Mol Biol 2008;31:235-238.

21. Martins C, Galetti PM. Chromosomal localization of 5S rDNA genes in Leporinus fish (Anostomidae, Characiformes). Chromosom Res 1999;7:363-367.

22. Hatanaka T, Galetti PM Jr. Mapping of the $18 \mathrm{~S}$ and $5 \mathrm{~S}$ ribosomal RNA genes in the fish Prochilodus argenteus Agassiz, 1829 (Characiformes, Prochilodontidae). Genetica 2004;122:239-244.

23. Palumbi SR: Nucleic acids II: the polymerase chain reaction. In: Molecular Systematics. Hillis DM, Moritz C, Mable BK (eds), pp. 205-247, Sinauer Associates, Sunderland, 1996.

24. Perdices A, Bermingham E, Montilla A, Doadrio I. Evolutionary history of the genus Rhamdia (Teleostei: Pimelodidae) in Central America. Mol Phylogenet Evol 2002; 25:172-189. 
25. Hall TA. BioEdit: a User-friendly biological sequence alignment editor and analysis program for Windows 95/98/NT. Nucleic Acids Symp Ser 1999;41:95-98.

26. Edgar RC. MUSCLE: multiple sequence alignment with high accuracy and high throughput. Nucleic Acids Res 2004;32:1792-1797.

27. Kumar S, Stecher G, Li M, Knyaz C, Tamura K. MEGA X: molecular evolutionary genetics analysis across computing platforms. Mol Biol Evol 2018;35:1547-1549.

28. Xia X. DAMBE7: new and improved tools for data analysis in molecular biology and evolution. Mol Biol Evol 2018; 35:1550-1552.

29. Darriba D, Taboada GL, Doallo R, Posada D. JModelTest 2: more models, new heuristics and parallel computing. Nat Methods 2012;9:772.

30. Puillandre N, Lambert A, Brouillet S, Achaz G. ABGD, Automatic Barcode Gap Discovery for primary species delimitation. Mol Ecol 2012;21:1864-1877.

31. Almeida-Toledo LF, Foresti F, Toledo Filho S. Spontaneous triploidy and NOR activity in Eigenmannia sp. (Pisces, Sternopygidae) from the Amazon basin. Genetica 1985;66:85-88.

32. Foresti F, Almeida-Toledo LF, Toledo-Filho SA. Polymorphic nature of nucleolus organizer regions in fishes. Cytogenet Cell Genet 1981;31:137-144.

33. Gornung E. Twenty years of physical mapping of major ribosomal RNA genes across the teleosts: a review of research. Cytogenet Genome Res 2013;141:90-102.

34. Vicari MR, Nogaroto V, Noleto RB, Cestari MM, Cioffi MB, Almeida MC, et al. Satellite DNA and chromosomes in Neotropical fishes: methods, applications and perspectives. J Fish Biol 2010;76:1094-1116.

35. Ferreira M, Kavalco KF, de Almeida-Toledo LF, Garcia C. Cryptic diversity between two Imparfinis species (siluriformes, heptapteridae) by cytogenetic analysis and DNA barcoding. Zebrafish 2014;11:306-317.

36. Cioffi MB, Martins C, Bertollo LA. Chromosome spreading of associated transposable elements and ribosomal DNA in the fish Erythrinus erythrinus. Implications for genome change and karyoevolution in fish. BMC Evol Biol 2010;10:217.

37. Merlo MA, Cross I, Manchado M, Cárdenas S, Rebordinos L. The 5S rDNA high dynamism in Diplodus sargus is a transposon-mediated mechanism. Comparison with other multigene families and sparidae species. J Mol Evol 2013;76:83-97.

38. Piscor D, Paiz LM, Baumgärtner L, Cerqueira FJ, Fernandes CA, Lui RL, et al. Chromosomal mapping of repetitive sequences in Hyphessobrycon eques (Characiformes, Characidae): a special case of the spreading of $5 \mathrm{~S}$ rDNA clusters in a genome. Genetica 2020;148:25-32.

39. Silva M, Barbosa P, Artoni RF, Feldberg E. Evolutionary dynamics of $5 \mathrm{~S}$ rDNA and recurrent association of transposable elements in electric fish of the family Gymnotidae (Gymnotiformes): the case of Gymnotus mamiraua. Cytogenet Genome Res 2016;149:297-303.

40. Kavalco KF, Pazza R, Bertollo LAC, Moreira-filho O. Heterochromatin characterization of four fish species of the family Loricariidae (Siluriformes). Hereditas 2004;141:237-242.

41. Ocalewicz K, Penman DJ, Babiak I. Variation in size and location of the Ag-NOR in the Atlantic halibut (Hippoglossus hippoglossus). Genetica 2008;133:261-267.

42. Baumgartner L, Paiz LM, Margarido VP, Portela-Castro ALB. Cytogenetics of the Thorny Catfish Trachydoras paraguayensis (Eigenmann \& Ward, 1907), (Siluriformes, Doradidae): evidence of Pericentric Inversions and Chromosomal Fusion. Cytogenet Genome Res 2016;149:201-206.
43. Fernandes CA, Paiz LM, Baumgärtner L, Margarido VP, Vieira MMR. Comparative cytogenetics of the black ghost knifefish (Gymnotiformes: Apteronotidae): evidence of chromosomal fusion and pericentric inversions in karyotypes of two Apteronotus species. Zebrafish 2017;14:471-476.

44. Fernandes CA, Baumgärtner L, Paiz LM, Margarido VP, Portela-Castro ALB. Chromosomal characteristics of rDNA in a conserved karyotype of two Sternopygus macrurus (Gymnotiformes: Sternopygidae) populations from upper Paraná River basin. Biol 2017;72:680-685.

45. Oliveira C, Avelino GS, Abe KT, Mariguela TC, Benine RC, Ortí G, et al. Phylogenetic relationships within the speciose family Characidae (Teleostei: Ostariophysi: Characiformes) based on multilocus analysis and extensive ingroup sampling. BMC Evol Biol 2011;11:275.

46. Kavalco KF, Pazza R, Brandão KDO, Garcia C, Bertollo LAC, de Almeida-Toledo LF. Chromosomal diversification higher than molecular variation in Astyanax aff. fasciatus (Teleostei, Characidae). Zebrafish 2016;13:345-353.

47. Rossini BC, Oliveira CA, Melo FA, Bertaco VA, Astarloa JM, Rosso JJ, et al. Highlighting Astyanax species diversity through DNA barcoding. PLoS One 2016;11:1-20.

48. Gavazzoni M, Pavanelli CS, Graça WJ, Melo BF, Gubiani ÉA, Margarido VP. Detection of natural hybridization and delimitation of two closely related operational taxonomic units of the Astyanax fasciatus (Teleostei: Characidae) complex through integrative approaches. Biol J Linn Soc 2020;129:687-700.

49. Costa-Silva GJ, Rodriguez MS, Roxo FF, Foresti F, Oliveira C. Using different methods to access the difficult task of delimiting species in a complex neotropical hyperdiverse group. PLoS One 2015;10:e0135075.

50. Melo BF, Dorini BF, Foresti F, Oliveira C. Little divergence among mitochondrial lineages of Prochilodus (Teleostei, Characiformes). Front Genet 2018;9:107.

51. Júlio Júnior HF, Tós CD, Agostinho ǍA, Pavanelli CS. A massive invasion of fish species after eliminating a natural barrier in the upper rio Paraná basin. Neotrop Ichthyol 2009; 7:709-718.

52. Abell R, Thieme ML, Revenga C, Bryer M, Kottelat M, Bogutskaya N, et al. Freshwater ecoregions of the world: a new map of biogeographic units for freshwater biodiversity conservation. Bioscience 2008;58:403-414.

53. Bonetto AA, Neiff JJ, Di Persia DH: The Paraná River system. In: The Ecology of River Systems. Davies BR and Walker KF (eds), pp. 541-555, Dr. W. Junk Publishers, Dordrecht, 1986.

54. Ringuelet RA. Zoogeografía y ecología de los peces de aguas continentales de la Argentina y consideraciones sobre las áreas ictiológicas de América del Sur. Ecosur 1975;2:1-122.

55. Ferraris CJ. Checklist of catfishes, recent and fossil (Osteichthyes: Siluriformes), and catalogue of siluriform primary types. Zootaxa 2007;1418:1-628.

Address correspondence to: Carlos Alexandre Fernandes, PhD Departamento de Biotecnologia,

Genética e Biologia Celular Universidade Estadual de Maringá Bloco H67, Avenida Colombo, 5790 Maringá CEP 87020-900

Paraná

Brazil

E-mail: fxande@gmail.com 